\title{
Occurrence and exposure assessment to aflatoxins in peanuts commercialized in the northwest of Parana, Brazil
}

\author{
Alini Cristini dos Santos ${ }^{1}$ Aline Amenencia de Souza ${ }^{2}$ Milena Veronezi Silva ${ }^{1}$ \\ Samuel Botião Nerilo $^{3}$ Alexandra Perdigão Maia de Souza ${ }^{1}$ \\ Érika Bando ${ }^{4}$ Miguel Machinski Junior ${ }^{4 *}$
}

${ }^{1}$ Programa de Pós-graduação em Ciência de Alimentos, Universidade Estadual de Maringá (UEM), Maringá, PR, Brasil. ${ }^{2}$ Programa de Pós-graduação em Ciências da Saúde, Universidade Estadual de Maringá (UEM), Maringá, PR, Brasil. ${ }^{3}$ Departamento de Farmácia, Centro Universitário Ingá (UNINGÁ), Maringá, PR, Brasil.

${ }^{4}$ Departamento de Ciências Básicas da Saúde, Universidade Estadual de Maringá (UEM), 87.020-900, Maringá, PR, Brasil. E-mail: mmjunior@uem.br. ${ }^{*}$ Corresponding author.

\begin{abstract}
Peanuts are a nutritious food consumed worldwide. Some species of the genus Aspergillus, producers of aflatoxins, colonize peanuts. Human exposure to aflatoxins occurs by ingesting contaminated foods. The objective of this paper was to assess the occurrence and dietary exposure of the population to aflatoxins in peanuts commercially available in Maringa, Brazil, from May 2013 to April 2017. A total of 104 peanut samples were evaluated by thin-layer chromatography and confirmed by derivatization with trifluoroacetic acid. The contamination rate detected was $24.0 \%$ in average concentration of $13.4 \mu \mathrm{g} / \mathrm{kg}$. Twenty positive samples (19.2\%) exceeded the maximum level permitted in Brazil for the sum of four aflatoxins. Estimated probable daily intake was 1,28 $\mu \mathrm{g} / \mathrm{kg}$ body weight/day, exceeding the Provisional Maximum Tolerable Daily Intake $(0.001 \mu \mathrm{g} / \mathrm{kg}$ body weight/day). According to the high levels of aflatoxins found in peanuts, there is need for further monitoring the presence of aflatoxins in peanuts in natura to reduce the levels of contamination.
\end{abstract}

Key words: aflatoxins, Aspergillus flavus, peanuts, risk assessment, public health.

Ocorrência e avaliação da exposição as aflatoxinas em amendoim comercializado na região noroeste do Paraná, Brasil

RESUMO: $O$ amendoim é um alimento nutritivo e muito consumido no mundo todo. Algumas espécies de fungos do gênero Aspergillus, produtores de aflatoxinas, colonizam o amendoim. A exposição humana as aflatoxinas ocorre por meio do consumo de alimentos contaminados. $O$ objetivo deste estudo foi avaliar a ocorrência e exposição da população as aflatoxinas em amendoim comercializado no município de Maringá, Brasil, durante o período de maio de 2013 a abril de 2017. Foram avaliadas 104 amostras de amendoim por análise cromatográfica e confirmadas por derivação com ácido trifluoroacético. A frequência de contaminação foi de 24,0\% em concentração média de $13,4 \mu \mathrm{g} / \mathrm{kg}$. Vinte amostras positivas (19,2\%) apresentaram-se acima do limite máximo permitido no Brasil para a somatória das quatro aflatoxinas. A

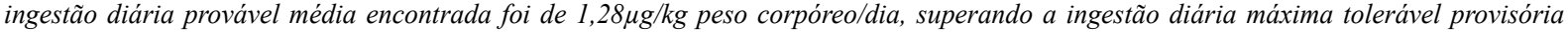
$(0,001 \mu \mathrm{g} / \mathrm{kg}$ peso corpóreo/dia). De acordo com os elevados teores de aflatoxinas encontrados em amendoim, há necessidade de um maior monitoramento da presença de aflatoxinas em alimentos, tendo em vista a redução nos níveis de contaminação do amendoim in natura. Palavras-chave: aflatoxinas, Aspergillus flavus, amendoim, avaliação de risco, Saúde Pública.

\section{INTRODUCTION}

Peanut (Arachis hypogaea) is a staple food of many people on earth. It is a low-cost source of fat, proteins, vitamins and minerals in the diet (BARBOUR et al., 2014). Peanut cultures are widely sensible to infection by fungi, mainly species producer of toxins, which mainly occurs during harvest and post-harvest, affecting quality and food safety (SOUZA et al., 2014). Mycotoxins are responsible for major economic losses that occur worldwide, due to problems to human and veterinary population, as damages in agricultural production (CAMILETTI et al., 2017). Aflatoxins of peanuts and derived assumes outstanding importance in public health, given the high consumption of these products, especially for children (MARTINS et al., 2017).

Occurrence of aflatoxins observed in peanuts in Latin America can be largely explained by the traditional practices of harvesting, drying and storage adopted by producers. In Brazil, climatic conditions behalf the development of toxin-producing fungi, as Aspergillus and aflatoxins. Worsening of this situation occurs during the Summer or conditions of high proliferation of insects (CAMILETTI et al., 2017; MARTINS et al., 2017).

Data on the occurrence of aflatoxins in Brazil revealed a high incidence. RODRIGUEZ- 
AMAYA (2001) demonstrated that 27 and $47 \%$ of the samples of peanuts from South and Southeast of Brazil were contaminated with aflatoxins, respectively. These samples were at levels above $20 \mu \mathrm{g} / \mathrm{kg}$, maximum limit for the presence of aflatoxins in peanuts in Brazil (ANVISA, 2011). MALLMAN et al. (2005) analyzed 664 samples of peanuts and their derivatives, $31.33 \%$ were contaminated with aflatoxins in Rio Grande do Sul. MAGRINE et al. (2010) analyzed samples of peanut and their derivatives commercialized in Paraná State. Of the 100 samples, $50(50 \%)$ had aflatoxin and 13 (13\%) with values higher than $20 \mu \mathrm{g} / \mathrm{kg}$.

Human exposure to aflatoxins at level measured in nanograms and micrograms per day occur mostly through the consumption of maize and peanuts, staple foods in tropical countries. The aim was to assess the ocurrence and dietary assesment of the population to aflatoxins in peanuts commercially available in the northwest of Parana State, Brazil, from May 2013 to April 2017.

\section{MATERIALS AND METHODS}

\section{Sampling}

Sampling was determined according to the annual per capita food acquisition of the Southern Region of Brazil on the Family Budget Survey (IBGE, 2008-2009). A total of 104 samples of three different brands of whole peanuts in natura were acquired from three supermarkets located in the city of Maringa, Parana State, Brazil, from May 2013 and April 2017. The three brands chosen for analysis stood out among the most sold in the region and were available to consumers during the period of sampling. A total of 2-3 samples were acquired per month. The selected supermarkets were located in different areas of the city of Maringa and represented the northwest region of Parana State. Weight of each sample was $500 \mathrm{~g}$. Samples were stored at $-20^{\circ} \mathrm{C}$ for a maximum of 30 days.

\section{Quality management}

Peanuts were analyzed in duplicates. Each analysis of approximately 11 samples was accompanied by one sample spiked with $20 \mu \mathrm{g} / \mathrm{kg}$ of aflatoxins $\mathrm{B}_{1}\left(\mathrm{AFB}_{1}\right)$ and $\mathrm{G}_{1}\left(\mathrm{AFG}_{1}\right)$ and $5 \mu \mathrm{g} / \mathrm{kg}$ of aflatoxins $\mathrm{B}_{2}\left(\mathrm{AFB}_{2}\right)$ and $\mathrm{G}_{2}\left(\mathrm{AFG}_{2}\right)$. Recovery rate between 70 and $140 \%$ was used as the analytical criterion, suggested by HORWITZ et al. (1993).

\section{Aflatoxins standards}

Aflatoxin standards were acquired from Sigma Chemical Co. (St.Louis, MO, USA). Standards solutions were made according to the official procedure AOAC method 971.22 (AOAC, 2005). Storage solutions were analyzed and quantified by ultraviolet spectrophotometer (Shimadzu UV-1601P, Tokyo, Japan) at 350nm. Using solutions were realized in benzene-acetonitrile $(98: 2, \mathrm{v} / \mathrm{v})$, containing $5 \mu \mathrm{g} / \mathrm{ml}$ $\mathrm{AFB}_{1}$ and $\mathrm{AFG}_{1}$ and, $1.5 \mu \mathrm{g} / \mathrm{ml} \mathrm{AFB}{ }_{2}$ and $\mathrm{AFG}_{2}$.

\section{Determination of aflatoxins in peanuts for thin-layer chromatography (TLC)}

The extration of aflatoxins was performed according to the method described by SOARES \& RODRIGUEZ-AMAYA (1989) using methanol, potassium chloride, copper sulfate, celite and chloroform. The chloroform phase was evaporated to dryness in a water bath at $80^{\circ} \mathrm{C}$. The residue thus obtained was resuspended in $400 \mu$ l of benzeneacetonitrile $(98: 2, \mathrm{v} / \mathrm{v})$ for analysis.

For screening and quantification, the mobile phase consisted of toluene-ethyl acetatechloroform-formic acid (35:25:25:10, v/v/v/v) for TLC, according to GIMENO (1979). Aflatoxins were visualized under UV light at $366 \mathrm{~nm}$ and quantified by fluorescence comparison by applying known volumes of samples and aflatoxin standards onto plates. All calculations were carried out according to the AOAC (2005). Identity of the aflatoxins was confirmed by chemical derivatization reactions with trifluoroacetic acid, as described by PRZYBYLSKI (1975).

\section{Determination of Average Probable Daily Intake $\left(P D I_{M}\right)$}

$\mathrm{PDI}_{\mathrm{M}}$ was calculated by multiplying the average concentration of the sum of the four aflatoxins $\left(B_{1}+B_{2}+G_{1}+G_{2}\right)$ reported in the samples analyzed in this study by the average consumption of peanutderived products in Paraná State $(6.7 \mathrm{~g} /$ person/day), based on the data reported by MAGRINE et al. (2011), divided by the average body weight of an adult $(70 \mathrm{~kg})$.

\section{RESULTS AND DISCUSSION}

The limit of quantification of the method was $2 \mu \mathrm{g} / \mathrm{kg}$ for $\mathrm{AFB}_{1}, \mathrm{AFB}_{2}, \mathrm{AFG}_{1}$ and $\mathrm{AFG}_{2}$ for TLC. The average recovery obtained by the method used was showed in table 1. According to the European Community the acceptable levels for recovery would be between $70-140 \%$, so the average recoveries remain within the acceptable range. Results reported in this research are similar to others studies (MAIA \& SIQUEIRA, 2002; SEKIYAMA et al., 2005; AMARAL et al., 2006). ROCHA et. al (2008) achieved a mean recovery for TLC method of $93 \%$ for the sum of the four aflatoxins in peanut. 
Table 1 - Recovery values $(\%)$ for aflatoxins in spiked peanuts $(\mathrm{n}=10)$

\begin{tabular}{|c|c|c|c|c|c|c|c|}
\hline \multirow{3}{*}{ Aflatoxins } & \multirow{3}{*}{$\mu \mathrm{g} / \mathrm{kg}$} & \multicolumn{5}{|c|}{----------------------------------------------Recovery (\%)-------------------------------------------- } & \multirow{3}{*}{$\begin{array}{c}\text { Mean } \\
\text { Recovery }(\%)\end{array}$} \\
\hline & & $1-2$ & $3-4$ & $5-6$ & $7-8$ & $9-10$ & \\
\hline & & $\mathrm{M}^{\mathrm{a}} \pm \mathrm{SD}^{\mathrm{b}}$ & $\mathrm{M} \pm \mathrm{SD}$ & $\mathrm{M} \pm \mathrm{SD}$ & $\mathrm{M} \pm \mathrm{SD}$ & $\mathrm{M} \pm \mathrm{SD}$ & \\
\hline $\mathrm{AFB}_{1}$ & 20 & $90 \pm 14$ & $140 \pm 85$ & $107 \pm 38$ & $107 \pm 38$ & $107 \pm 38$ & 106.0 \\
\hline $\mathrm{AFB}_{2}$ & 5 & $140 \pm 38$ & $90 \pm 14$ & $140 \pm 14$ & $80 \pm 0$ & $120 \pm 57$ & 120.0 \\
\hline $\mathrm{AFG}_{1}$ & 20 & $80 \pm 0$ & $90 \pm 14$ & $120 \pm 57$ & $107 \pm 38$ & $107 \pm 38$ & 106.7 \\
\hline $\mathrm{AFG}_{2}$ & 5 & $90 \pm 14$ & $80 \pm 0$ & $140 \pm 38$ & $80 \pm 0$ & $90 \pm 14$ & 90.0 \\
\hline
\end{tabular}

${ }^{\mathrm{a}}$ Mean. ${ }^{\mathrm{b}}$ Standard deviation.

Results reported for the occurrence of aflatoxins in peanuts commercially available in northwest of Parana are presented in table 2. Data revealed a high frequency of aflatoxins in the samples. Of the 104 samples analyzed, $24.0 \%$ were contaminated by aflatoxins, and 20 samples $\left(\mathrm{AFB}_{1}+\mathrm{AFB}_{2}+\mathrm{AFG}_{1}+\mathrm{AFG}_{2}\right)$ above $20 \mu \mathrm{g} / \mathrm{kg}$, maximum limit for the presence of aflatoxins in peanuts in Brazil (ANVISA, 2011). In the present study, three of the samples were reported to be contaminated with detectable levels of $\mathrm{AFG}_{1}$ or $\mathrm{AFG}_{2}$.

Levels of aflatoxins $\left(B_{1}+B_{2}+G_{1}+G_{2}\right)$ in the positive samples analyzed ranged from $8-832 \mu \mathrm{g} / \mathrm{kg}$. A comparison of the results reported in this study with other studies realized in Brazil demonstrated that the occurrence of aflatoxins in the analyzed samples continue to be a risk for health of Brazilian population (Table 3 ).

However, levels of aflatoxins reported in this study were higher than those reported in other countries. IQBAL et al. (2013) evaluated 198 samples of peanuts and derivatives commercialized in Punjab, Pakistan and related that $93(47 \%)$ samples were positive for aflatoxins, of which $16 \%(32 / 98)$ exceeded $4 \mu \mathrm{g} / \mathrm{kg}$, maximum limit set by the European Union (EC, 2006). BANKOLE et al. (2005) reported that $64.2 \%$ of dry-roasted ground peanuts commercialized in Nigeria were contaminated with $\mathrm{AFB}_{1}$, average concentration of $25.5 \mu \mathrm{g} / \mathrm{kg}$.

The $\mathrm{PDI}_{\mathrm{M}}$ reported in this study was $1.28 \mu \mathrm{g} /$ $\mathrm{kg}$ body weight (b.w.)/day. This intake was higher than that estimated by other authors. JAGER et al. (2013) related a $\mathrm{PDI}_{\mathrm{M}}$ of $0.0137 \mu \mathrm{g} / \mathrm{kg}$ b.w./day for the sum of the four aflatoxins. MAGRINE et. al. (2011) determined $\mathrm{PDI}_{\mathrm{M}}$ for aflatoxin $\mathrm{B}_{1}$ and reported a value of $0.010 \mu \mathrm{g} /$ $\mathrm{kg} \mathrm{b}$.w./day for high consumption of peanuts.

Despite the lack of consensus on the Acceptable Daily Intake (ADI) for aflatoxins, KUIPERGOODMAN (1998) proposed a Provisional Maximum Tolerable Daily Intake (PMTDI) of $0.001 \mu \mathrm{g} / \mathrm{kg}$ b.w./ day of $\mathrm{AFB}_{1}$ for adults and children without a diagnosis of the Hepatitis B virus and of $0.0004 \mu \mathrm{g} / \mathrm{kg}$ b.w./day of $\mathrm{AFB}_{1}$ for carriers of the Hepatitis B virus. The $\mathrm{PDI}_{\mathrm{M}}$ for $\mathrm{AFB}_{1}(3.99 \mu \mathrm{g} / \mathrm{kg}$ b.w./day) obtained in the present study exceeded the PMTDI values, demonstrating the importance of new studies to assess the risks to human health through exposure to aflatoxins in Brazil.

\section{CONCLUSION}

According to the high levels of aflatoxin reported in the analyzed samples, there is a need of

Table 2 - Aflatoxin levels in samples of peanuts commercialized in Maringa, Brazil (May 2013 to April 2017).

\begin{tabular}{|c|c|c|c|c|c|c|}
\hline \multirow{2}{*}{ Aflatoxins } & \multirow{2}{*}{$\mathrm{N}^{\circ}$ positive samples } & \multirow{2}{*}{ Occurrence $(\%)$} & \multicolumn{2}{|c|}{---------------Total samples-------------- } & \multicolumn{2}{|c|}{---------Positive samples--------- } \\
\hline & & & Mean $(\mu \mathrm{g} / \mathrm{kg})$ & Range $(\mu \mathrm{g} / \mathrm{kg})$ & Mean $(\mu \mathrm{g} / \mathrm{kg})$ & Range $(\mu \mathrm{g} / \mathrm{kg})$ \\
\hline $\mathrm{B}_{1}$ & 25 & 24.0 & 41.7 & $2-720$ & 163.4 & $8-720$ \\
\hline $\mathrm{B}_{2}$ & 21 & 20.2 & 7.0 & $2-112$ & 27.6 & $2.4-112$ \\
\hline $\mathrm{G}_{1}$ & 3 & 2.9 & 2.8 & $2-53.3$ & 28.4 & $16-53.3$ \\
\hline $\mathrm{G}_{2}$ & 3 & 2.9 & 2.1 & $2-4.8$ & 4.5 & $4-4.8$ \\
\hline $\mathrm{B}_{1}+\mathrm{B}_{2}+\mathrm{G}_{1}+\mathrm{G}_{2}$ & 25 & 24.0 & 13.4 & $2-832$ & 79.7 & $8-832$ \\
\hline
\end{tabular}


Table 3 - Occurrence and levels of aflatoxins in peanuts in the Brazil.

\begin{tabular}{|c|c|c|c|c|c|}
\hline Year & State & $\begin{array}{c}\text { Occurrence } \\
(\%)\end{array}$ & $\begin{array}{c}B_{1}+B_{2}+G_{1}+G_{2} \\
\text { Medium }(\mu \mathrm{g} / \mathrm{kg})\end{array}$ & $\begin{array}{l}B_{1}+B_{2}+G_{1}+G_{2} \\
\text { Higher }(\mu \mathrm{g} / \mathrm{kg})\end{array}$ & References \\
\hline 2017 & Sao Paulo & $12 / 119$ & $\mathrm{ND}^{\mathrm{a}}$ & 100.9 & MARTINS et al., 2017 \\
\hline 2012 & Sao Paulo & $8 / 23(35)$ & $8.5 \pm 12.7$ & 36.7 & JAGER et al., 2013 \\
\hline 2011 & Federal District & $29 / 359(8)$ & $14.2 \pm 85.1$ & 1496 & ANDRADE et al., 2013 \\
\hline 20112010 & Sao Paulo & $\mathrm{ND}^{\mathrm{a}}$ & $\mathrm{ND}^{\mathrm{a}}$ & 26052 & INAMURA et al., 2014 \\
\hline 2010 & Rio Grande do Sul & $7 / 12(58)$ & 16.2 & 126.2 & OLIVEIRA \& KOLLER, 2011 \\
\hline 2009 & Sao Paulo & $12 / 75(16)$ & $\mathrm{ND}^{\mathrm{a}}$ & $\mathrm{ND}^{\mathrm{a}}$ & SILVA et al., 2013 \\
\hline 2007 & Parana & $5 / 10(50)$ & 3.4 & 21.9 & MAGRINE et al., 2011 \\
\hline 2007 & Sao Paulo & $19 / 48(40)$ & $12.8 \pm 2.42$ & $\mathrm{ND}^{\mathrm{a}}$ & OLIVEIRA et al., 2009 \\
\hline 2007 & Minas Gerais & $8 / 21(38)$ & 64.0 & $\mathrm{ND}^{\mathrm{a}}$ & ROCHA et al., 2008 \\
\hline 2002 & Parana & $1 / 6(17)$ & $\mathrm{ND}^{\mathrm{a}}$ & 3422 & EIZENDEHER et al., 2005 \\
\hline 2001 & Sao Paulo & $56 / 87(64)$ & 306 & 1659 & SHUNDO et al., 2003 \\
\hline 2000 & Federal District & $26 / 53(49)$ & 107 & 1421 & CALDAS et al., 2002 \\
\hline
\end{tabular}

${ }^{\mathrm{a}}$ Not determined.

monitoring the presence of aflatoxins in peanuts in natura in order to reduce the levels of contamination in food commercialized in northwest of Parana, Brazil. Risk of hepatocellular carcinoma present in the diet of the studied population has shown to be greater than thated report in other countries and may represent a health problem for this population. Other researches need to becarried out to assess the risk of human exposure to aflatoxins, with a view to $\mathrm{PDI}_{\mathrm{M}}$ reported.

\section{ACKNOWLEDGEMENTS}

The authors would like to thank the Coordenação de Aperfeiçoamento de Pessoal de Nível Superior (CAPES) for scholarships granted to the first, second, third and fifth author author.

\section{CONFLICTS OF INTEREST}

The authors declare no conflict of interest. The founding sponsors had no role in the design of the study; in the collection, analyses, or interpretation of data; in the writing of the manuscript, and in the decision to publish results.

\section{REFERENCES}

AOAC. Association of Official Agricultural Chemists.Official. Methods of Analysis of the Association of Analytical Chemists, $17^{\text {th }}$ ed. Arlington: AOAC, 2005.

AMARAL, K.A.S. et al. Aflatoxinas em produtos à base de milho comercializados no Brasil e riscos para a saúde humana. Ciência e Tecnologia de Alimentos, Campinas, v.26, p.336-342, 2006. Available from: $<$ http://www.scielo.br/scielo.php?Script $=$ sci arttext\&pid $=\mathrm{S} 0101-20612006000200016 \& \operatorname{lng}=\mathrm{en} \& \mathrm{nrm}=\mathrm{iso}>$. Accessed: Aug. 30, 2017. doi: 10.1590/S0101-20612006000200016.
ANDRADE, P.D. et al. Aflatoxins in food products consumed in Brazil: a preliminary dietary risk assessment. Food Additives and Contaminants: Part A, Abingdon, v.30, p.127-136, 2013. Available from: <http://www.tandfonline.com/doi/full/10.1080/19440049.2012.7 20037>.Accessed:Aug. 30,2017. doi: 10.1080/19440049.2012.720037.

ANVISA. Agência Nacional de Vigilância Sanitária. Resolução RDC N 7. Brasília: Diário Oficial da União, 18 de fevereiro de 2011.

BANKOLE, S.A. et al. Aflatoxins in Nigerian dryroasted groundnuts. Food Chemistry, London, v.89, p.503-506, 2005. Available from: $<$ http:// www.sciencedirect.com/science/article/pii/S0308814604002341>. Accessed: Aug. 30, 2017. doi: 10.1016/j.foodchem.2004.03.004.

BARBOUR, J.A. et al. Lower energy intake following consumption of Hi-oleic and regular peanuts compared with isso-energetic consumption of potato crisps. Appetite, London, v.82, p. 124-130, 2014. Available from: <http://www.sciencedirect.com/science/article/ pii /S0195666314003729>. Accessed: Dec. 22, 2017. doi: 10.1016/j. appet. 2014.07.015.

CAMILETTI, B.X. et al. Fungal screening and aflatoxin production by Aspergillus section Flavi isolated from pre-harvest maize ears grown in two Argentine regions. Crop Protection, Guildford. Available from: <http://ac.els-cdn.cm/S0261219416302903>. Accessed: Dec. 22, 2017. doi: 10.1016/j.cropro. 2016.10.012

EC. European Commission Regulation. Maximum levels for certain contaminants in foodstuffs. Official Journal of the European Union, No. 1881 of 19 December 2006.

EIZENDEHER, L.B. et al. Incidence of aflatoxins $B_{1}, B_{2}, G_{1}$ and $G_{2}$ in fresh peanut and peanut sweets marketed in the State of Paraná. Higiene Alimentar, Mirandopólis, v.19, p.101-104, 2005. Available from: $<$ http:/higienealimentar.com.br/edicoes/sobremesas-lacteas-comfrutas-tropicais-marco-nutricional-41.html >. Accessed: Aug. 30, 2017.

GIMENO, A. Thin-layer chromatographic determination of aflatoxins, ochratoxins, sterigmatocystin, zearalenone, citrinin, T-2 toxin, diacetoxyscirpenol, penicillic acid, patulin, and penitrem 
A. Journal of Association of Official Analytical Chemists, Arlington, v.62, p.579-585, 1979.

HORWITZ, W. et al. Reliability of mycotoxin assays - an update. Journal of AOAC International, Arlington, v.76, p.461-491, 1993. Available from: <https://www.ncbi.nlm.nih.gov/labs/articles/8318839/>. Accessed: Aug. 31, 2017.

IBGE. Instituto Brasileiro de Geografia e Estatística. Pesquisa de Orçamentos Familiares (2008-2009). Aquisição Alimentar Domiciliar per Capita Brasil e Grandes Regiões. Rio de Janeiro: IBGE, 2010. Available from: <http://www.ibge.gov.br/ home/estatistica/populacao/condicaodevida/pof/2008_2009 aquisicao/>. Accessed: Jan. 20, 2015.

INAMURA, K.B. et al. Incidence of aflatoxins in the raw peanut (Arachis hypogaea L.) in shell of Alta Paulista-SP region during the period from 2011 to 2012. Revista do Instituto Adolfo Lutz, São Paulo, v.73, p.178-187, 2014. Available from: <http://revistas.bvs-vet. org.br/rialutz/article/view/27445/28751>. Accessed: Aug. 31, 2017. doi: $10.18241 / 0073-98552014731603$.

JAGER, A.V. et al. Assessment of aflatoxin intake in São Paulo, Brazil. Food Control, Guildford, v.33, p.87-92, 2013. Available from: $<$ http:// www.sciencedirect.com/science/article/pii/S0956713513000923>. Accessed: Aug. 31, 2017. doi: 10.1016/j.foodcont.2013.02.016.

KUIPER-GOODMAN, T. Food safety: mycotoxins and phytotoxins in perspective. In: Mycotoxins and Phytotoxins e Developments in Chemistry, Toxicology and Food Safety. Fort Collins: Alaken, 1998. p.25-48.

MAIA, PP.; SIQUEIRA, MEPB. Occurrence of aflatoxins $B_{1}$, $B_{2}, G_{1}$ and $G_{2}$ in some Brazilian pet foods. Food Additives and Contaminants, London, v.19, p.1180-1183, 2002. Available from: $<$ http://www.tandfonline.com/doi/abs/10.1080/026520302100001121 4>. Accessed: Aug. 31, 2017. doi: 10.1080/0265203021000011214.

MAGRINE, I.C.O. et al. Intake of aflatoxins through the consumption of peanut products in Brazil. Food Additives and Contaminants: Part B, London, v.4, p.99-105, 2011. Available from: $<$ http://www.tandfonline. com/doi/abs/10.1080/19393210.2011.561931? journalCode $=$ tfab20> . Accessed: Aug. 31, 2017. doi: 10.1080/19393210.2011.561931.

MALLMAN, C.A. et al. Prevalência de aflatoxinas em amendoim e seus derivados, destinados ao consumo humano, no estado do Rio Grande do Sul. In: SIMPÓSIO EM CIÊNCIA DE ALIMENTOS, 2. 2005, Florianopólis, Brasil. Anais... Florianopólis: SBCTA, 2005.

MARTINS, C.M. et al. The biodiversity of Aspergillus section Flavi and aflatoxins in the Brazilian peanut production chain. Food Research International, Barking, v.94, p.101-107, 2017. Available from: <http://ac.els-cdn.com/S0963996917300583>. Accessed: Dec. 22, 2017. doi: 10.1016/j.foodres.2017.02.006.
OLIVEIRA, CAF. et al. Determination of aflatoxins in peanut products in the northeast region of São Paulo, Brazil. International Journal of Molecular Sciences, Basel, v.10, p.174-183, 2009. Available from: $<$ http://www.mdpi.com/1422-0067/10/1/174>. Accessed: Aug. 31, 2017. doi: 10.3390/ijms10010174.

OLIVEIRA, LSF.; KOLLER, FFC. Occurrence of Aspergillus and aflatoxin in samples of peanuts in natura and peanut sweet. Revista de Ciências Ambientais, Canoas, v.5, p.57-68, 2011. Available from: <http://www.revistas.unilasalle.edu.br/index.php/Rbca/article/ view/137/154>. Accessed: Aug. 31, 2017.

PRZYBYLSKI, W. (1975). Formation of aflatoxin derivatives on thin layer chromatographic plates. Journal of Association of Official Analytical Chemists, Arlington, v.58, p.163-164, 1975.

ROCHA, M.D. et al. Incidence of aflatoxins in samples of peanut and peanut candy marketed in the city of Alfenas-MG, Brazil. Revista Brasileira de Toxicologia, São Paulo, v.21, p.15-19, 2008.

RODRIGUEZ-AMAYA, D.B. Occurrence of mycotoxins and mycotoxin-producing fungi in Latin America. In: KOE, W.J. et al. Mycotocins and phycotoxins in perspective at the turn of the millenium. Wageningen: W. J. de Koe, 2001, p.309-320.

SEKIYAMA, B.L. et al. Aflatoxins, ochratoxin A and zearalelone in maize-based food products. Brazilian Journal of Microbiology, São Paulo, v.36, p.289-294, 2005. Available from: $<$ http://www.scielo.br/ scielo.php?script=sci_arttext\&pid=S1517-83822005000300016>. Accessed: Aug. 31, 2017. doi: 10.1590/S1517-83822005000300016.

SHUNDO, L. et al. Ocorrência de Aflatoxinas em amendoim e produtos de amendoim comercializados na região de Marília SP, Brasil no período de 1999-2001. Revista do Instituto Adolfo Lutz, São Paulo, v.62, p.177-181, 2003.

SILVA, R.A. et al. Detection and quantification of aflatoxins in samples of peanut grains and derivatives traded in the MariliaSP region, 2002-2009. Alimentos e Nutrição, Araraquara, v. 24, p.61-64, 2013. Available from: <http://serv-bib.fcfar.unesp.br/seer/ index.php/alimentos/article/viewFile/3134/1427>. Accessed: Aug. $31,2017$.

SOARES, LMV;; RODRIGUEZ-AMAYA, DB. Survey of aflatoxins, ochratoxin A, zearalenone, and sterigmatocystin in some Brazilian foods by using multi-toxin thin-layer chromatographic method. Journal of Association of Official Analytical Chemists, Arlington, v.72, p.22-26, 1989.

SOUZA, G.F. et al. Evaluation of the mycoflora and aflatoxins from the pre-harvest to storage of peanuts: a case study. Acta Scientiarum: Agronomy, v.36, p.27-33, 2014. Available from: $<\mathrm{http}: / /$ periodicos. uem.br/ojs/index.php/ActaSciAgron/article/view/16972>. Accessed: Aug. 31, 2017. doi: 10.4025/actasciagron.v36i1.16972. 